\title{
Drugs dispensed at the Division of Neonatology at University Hospital in Río Cuarto, Córdoba, Argentina
}

\author{
Marta Stella Maris Fungo, Pharmacist ${ }^{a}$ and Elena María Vega, PhD in chemestry. ${ }^{b}$
}

\begin{abstract}
Introduction. The objective was to analyze the number of drugs dispensed by the Pharmacy Department to the Neonatology Division, to find out if the use of these drugs is described on the package insert approved by the Administración Nacional de Medicamentos, Alimentos y Tecnología, ANMAT (Drug, Food and Technology Administration of Argentina) and to compare such information with that provided by Medical Associations and Commissions.

Population and methods. Analytical, observational and retrospective study in which drugs were analyzed based on dosage units, costs and relevance in the 2011 annual budget. We analyzed the information found in ANMAT-approved label inserts, in the Neonatal Pharmacopeia of the Sociedad Argentina de Pediatría and in the Formularies of the Confederación Médica Argentina and the Comisión Nacional del Medicamento (National Medication Commission).

Results. A total of 102 drugs (91 drug substances) were dispensed throughout 2011. Drugs most commonly supplied were: antiinfective agents for systemic use $(24.51 \%)$, agents for the blood and blood forming organs, cardiovascular system, and nervous system $(12.72 \%$ each). The total expenditure was ARS 263,285.52. Only 21 drugs accounted for $90.73 \%$ of the cost. Out of the 14 drugs in this group, only 1 had information related to its use in neonatology in all its labels (package inserts), only 4 in some of their product information and there was no information at all in any of the remaining 9 drugs. The Neonatal Pharmacopeia reported on 12 of the 14 drugs, while the Formularies made a reference to 9 of the 14 drugs.

Conclusions. The most widely used drugs were antiinfectives for systemic use. A total of 21 drugs accounted for $90.73 \%$ of the annual cost in drugs. Out of 14 , only 1 had information of its use in neonatology in all its labels and 9 corresponded to off-label use.
\end{abstract}

Key words: neonatology, drug information services, drug use, formularies, off-label use.

http:/ /dx.doi.org/10.5546/aap.2013.120

\section{INTRODUCTION}

Since 1995, the American Academy of Pediatrics has dealt with the subject of the use of drugs in newborn infants and children. In Argentina, there is also interest in it, especially because drugs are not being used in compliance with label specifications (off-label use) or because such use is not authorized in children (unlicensed use). ${ }^{1-4}$

In our setting, it is estimated that in relation to third-level hospital pediatric hospitalization units, the number of off-label drug prescriptions might be around $40 \%$, and this figure is even higher in neonatology units. ${ }^{3,4}$.

Likewise, the uniqueness of the development of newborn infants, and the fact that at present, more and more premature infants survive, have a major impact on the cost of drug therapy. ${ }^{5}$

Also, the absence of adequate commercial dosage forms, the scarce information on the use of drugs in this age group and the lack of approval of drugs habitually used in the pediatric clinical practice are all aspects that specifically affect these patients, both from the clinical standpoint when writing a prescription, and at the time of providing adequate pharmaceutical care. $^{6}$

An ideal clinical use should be based on safety and effectiveness data regarding each specific agent; it is therefore necessary to carefully describe the possibilities of use in terms of each indication. Kinetic features should also be taken into account to better define usage and dosage in each particular case; and last, but not least, other factors should be considered like ease-ofmanagement (route of administration) and cost. ${ }^{7}$

Based on the formerly stated information, it is understood that the conduction of pediatric clinical trials is the way to warrant that children will receive safe and effective drugs. ${ }^{8}$ According to Giglio, ${ }^{4} 22$ pediatric clinical trials have been registered 
for Argentina in the web site ClinicalTrials.gov between 2008 and 2010, together with 10 trials which included children and adults, but this is a small number when compared to studies conducted on adults.

The Nuevo Hospital Río Cuarto (NHRC) San Antonio de Padua is a teaching hospital located in the city of Río Cuarto, Province of Córdoba, Argentina. It is a third-level hospital with 202 beds. Out of these 202 beds, 8 are in the neonatal intensive care unit (NICU), 10 in the neonatal intermediate care unit and 16 are rooming-in units shared with the Obstetrics Department; $16.83 \%$ of the beds are for newborn infants.

The Department of Pharmacy (PD) dispenses drugs and other supplies to the Division of Neonatology. In order to provide adequate counseling on the use of drugs in newborn infants, the PD should know what the most commonly used drugs are in the Division of Neonatology. Hence, training activities can be performed on drug delivery and management efforts can be focused on reducing high cost drugs. It is also possible to study the use of drugs which have not been approved by health authorities for this group of patients.

The objective of this article was to analyze the number of drugs dispensed by the Department of Pharmacy to the Division of Neonatology, find out if the use of these drugs in neonatology is described in the label approved by the ANMAT and compare this information with that provided by Medical Associations and Commissions.

\section{POPULATION AND METHODS}

In the first stage, an analytical, observational and retrospective study was done on the use of drugs, including a description of units dispensed to the Division of Neonatology and their costs. ${ }^{9}$ 2011.

Study period: January $1^{\text {st. }}$ to December $31^{\text {st. }}$, llows:

The recorded outcome variables were as fo-

- Number of dosage units (tablets, capsules, vials, etc.) of each drug dispensed each month.

- Unit drug cost obtained in the competitive bidding by the NHRC, corresponding to December 2011.

a A public bidding is the process employed by the NHRC to acquire drugs. It consists of requesting written quotations from providers authorized by the Ministry of Health of the Province and the bid is awarded to the most convenient out of, at least, two actual quotations.
Different drugs were defined as those that, even though they have the same active ingredient (drug substance), are presented in different pharmaceutical forms. For example, metoclopramide drops and vials were regarded as two different drugs. In addition, a bottle of metoclopramide drops was considered one unit dosage, while a metoclopramide vial was considered a different dosage unit.

All drugs that were dispensed by the Department of Pharmacy to the NHRC's Division of Neonatology were included and recorded in transfer sheets. Compounded preparations made by the NHRC's Division of Neonatology and drugs donated or acquired by family members were excluded.

Drug dispensation to the Division of Neonatology follows a traditional scheme and is based on the available stock. ${ }^{10}$

There were three drugs (human insulin 100 IU vial, bovine pulmonary surfactant $120 \mathrm{mg}$ vial, lansoprazole $15 \mathrm{mg}$ medicine bags) with no cost description included in the public bidding, so their price was established as per the Manual Farmacéutico AlfaBeta, ${ }^{11}$ updated as of December $13^{\text {th }}$, 2011. Such cost corresponds to retail prices.

All drugs were categorized according to the Anatomical Therapeutic Chemical Classification system (ATC)..$^{12}$ This is a consistent classification of active ingredients, that is generalizable across countries and stable over time, adopted by the WHO to systematize and compare data obtained in the different studies. ${ }^{13}$

The Pareto's analysis was performed using the above mentioned outcome variables. ${ }^{14}$ This analysis, also known as the "80/20 rule or principle", allows to determine which drugs account for $80 \%$ of the budget based on their high cost or large quantity. This information is useful to maximize the economic and pharmacotherapeutic management at the Division of Neonatology. ${ }^{15}$

Category A includes drugs that accounted for $80 \%$ of the budget. Category B includes drugs that accounted for the next $10 \%$, to reach $90 \%$ of the budget; and category $\mathrm{C}$ includes the remaining $10 \%$.

The second phase of the study consisted of analyzing the information available on the use of these drugs in neonatology. Drugs included were those in groups A and B of the Pareto's analysis; parenteral solutions were excluded because they were considered vehicles for other drugs.

The official labels of each drug were looked up in the Vademécum farmacológico (Pharmacopeia) in the ANMAT's web site. ${ }^{16}$ 
Information was also retrieved from the Neonatal Pharmacopeia of the Sociedad Argentina de Pediatría, ${ }^{17}$ the Formulary of the Confederación Médica Argentina, COMRA ${ }^{18}$ and the Formulary of the Comisión Nacional del Medicamento (CONAMED). ${ }^{19}$ Information was considered affirmative if it referred to "newborn infants," "premature infants" either in the Indications or in the Dosage sections.

\section{RESULTS}

According to the Department of Pharmacy records, 102 different drugs, corresponding to 91 drug substances, were dispensed to the Division of Neonatology throughout 2011. Drug expenditure was USD 60,455.92.

Table 1 shows drugs arranged as per ATC code groups. Among the most commonly dispensed drugs, $25(24.51 \%)$ corresponded to the Group J (antiinfectives for systemic use). Groups B (blood and blood forming organs), C (cardiovascular system), and $\mathrm{N}$ (nervous system) occupied the second place with 13 (12.72\%) different drugs each.

The Pareto's analysis was used to know which drugs were most used in 2011, and the cost of units administered in terms of the unit cost and amounts dispensed.

Out of the 102 drugs supplied, only $9.80 \%$ (10) were included in group A, accounting for $80.62 \%$ (ARS 212,255.28) of the total annual purchased in ARS. In group B, $10.78 \%$ (11) of drugs accounted for $10.11 \%$ (ARS 26,614.35) of the annual expenditure, while the remaining $79.41 \%$ (81) corresponded to group C and accounted for $9.27 \%$ (ARS $24,415.89$ ) of the annual expenditure in the NICU.

Groups A and B together accounted for $90.73 \%$ of the expenditure, corresponding to $20.58 \%$ of all drugs used in the Division of Neonatology. The description of drugs included in these groups, unit consumption, unit cost and total cost are shown in Table 2.

Fourteen of the 21 drugs corresponding to groups A and B were taken into account to analyze if there was any description of their use in neonatology.

The analysis of labels published in ANMAT's web site showed that in 1 drug all similar marketed products have information for its use in this age group, while in 9 out of these 14 drugs there is no indication of their use in newborn infants.

Information about 12 of 14 medicines was found in the Neonatal Pharmacopeia of the Sociedad Argentina de Pediatría. The two formularies analyzed included information for 9 drugs, but these were not necessarily the same ones.

Information retrieved from the different sources is summarized in Table 3.

\section{DISCUSSION}

Resources that society may assign to health in general or to drugs in particular, are limited. This situation makes it necessary to evaluate the expenditure generated by the different health strategies, including drugs, as a significant outcome variable. Over the past years, concern has been raised regarding the increase in drug expenditure. However, in order to evaluate this information, it has to be placed in the more global context of health expenditure and provide detailed information regarding the characteristics of the use of drugs leading to such expenditure. ${ }^{20}$ The general annual 2011 budget assigned to the NHRC for the purchase of drugs and medical supplies was USD

TABLE 1. Number of drugs arranged per anatomical therapeutic main group of the ATC code

\begin{tabular}{lcc}
\hline Anatomical main group as per Anatomical Therapeutic Chemical Classification (ATC) & Drugs ( ) & Percentage \\
\hline J (antiinfectives for systemic use) & 25 \\
B (blood and blood forming organs) & 13 \\
C (cardiovascular system) & 13 \\
N (nervous system) & 12.7 \\
A (alimentary tract and metabolism) & 12.7 \\
V (various) & 10.8 \\
R (respiratory system) & 9.8 & 11 \\
D (dermatologicals) & 5.9 & 6 \\
H (systemic hormonal preparations) & 3.9 \\
S (sensory organs) & 2.9 & 3 \\
M (musculo-skeletal system) & 2.9 & 3 \\
Total & 1.0 & 10 \\
\hline
\end{tabular}




\section{$2,296,211.25 .^{21}$}

The analysis of the results shows that the expenditure in drugs dispensed to the NHRC's Division of Neonatology accounted for $2.63 \%$ (ARS $263,285.52$ ) of the total annual budget. In this context, expenditure in neonatology drugs does not seem to be an important item in the budget. It should be noted that, in this study, only the price of the dispensed drugs was taken into account. No other costs were considered, such as medical products, nor the value of discarded drugs was quantified when they were not completely used due to lack of stability or problems with the right dose. The expenditure related to drug misuse, for example hospitalization extension, was not verified either.

During 2011, the Department of Pharmacy dispensed 102 different drugs to the Division of Neonatology without taking compounded preparations into account. This value agrees with that of a Spanish study in which authors recorded 816 prescriptions corresponding to 102 different

TABLE 2. Description of drugs included in groups A and B; unit consumption, unit cost and total cost

\begin{tabular}{|c|c|c|c|c|c|c|}
\hline Group & ATC code & Drugs & $\begin{array}{l}\text { Consumption } \\
\text { (units) }\end{array}$ & $\begin{array}{l}\text { Unit cost } \\
\text { (ARS) }\end{array}$ & $\begin{array}{l}\text { Total cost } \\
\text { (ARS) }\end{array}$ & $\begin{array}{l}\text { Cumulative } \\
\text { percentage }\end{array}$ \\
\hline \multirow[t]{10}{*}{ A } & R07AA & $\begin{array}{c}\text { Pulmonary surfactant } 120 \mathrm{mg} \\
\text { vial }\end{array}$ & 126 & 785.00 & $98,910.00$ & 37.57 \\
\hline & J02AA01 & $\begin{array}{c}\text { Liposomal amphotericin B } 50 \mathrm{mg} \\
\text { vial }\end{array}$ & 30 & 1980.00 & $59,400.00$ & 60.13 \\
\hline & V07AB & Sterile distilled water $5 \mathrm{~mL}$ & 9800 & 1.38 & $13,524.00$ & 65.27 \\
\hline & J01DH02 & $\begin{array}{l}\text { Meropenem } 500 \text { mg } \\
\text { vial }\end{array}$ & 264 & 34.00 & 8976.00 & 68.67 \\
\hline & V07AB & $0.9 \%$ sodium chloride $100 \mathrm{~mL}$ & 1756 & 3.75 & 6585.00 & 71.18 \\
\hline & V07AB & $0.9 \%$ sodium chloride $5 \mathrm{~mL}$ & 4300 & 1.45 & 6235.00 & 73.54 \\
\hline & A10AB01 & $\begin{array}{c}\text { Human insulin } \\
\text { (as protamine zinc insulin) } \\
100 \mathrm{IU} 10 \mathrm{~mL} \\
\text { vial }\end{array}$ & 23 & 247.36 & 5689.28 & 75.70 \\
\hline & B05AA01 & $\begin{array}{l}20 \% \text { human serum albumin } \\
50 \mathrm{~mL}\end{array}$ & 40 & 135.00 & 5400.00 & 77.76 \\
\hline & В03ВВ01 & $\begin{array}{c}\text { Folic acid50 mg/10 mL } \\
\text { dropper vial }\end{array}$ & 120 & 32.00 & 3840.00 & 79.21 \\
\hline & B03XA01 & $\begin{array}{c}\text { Recombinant human } \\
\text { erythropoietin alpha } 2000 \mathrm{IU} \\
\text { vial }\end{array}$ & 264 & 14.00 & 3696.00 & 80.62 \\
\hline \multirow[t]{12}{*}{ B } & B05XB & $\begin{array}{l}10 \% \text { amino acids } 500 \mathrm{~mL} \\
\text { vial }\end{array}$ & 36 & 89.00 & 3204.00 & 81.83 \\
\hline & V07AB & Sterile distilled water $500 \mathrm{~mL}$ & 830 & 3.84 & 3187.20 & 83.05 \\
\hline & C01EA01 & $\begin{array}{l}\text { Alprostadil } 500 \mu \mathrm{g} / \mathrm{mL} \\
\text { vial }\end{array}$ & 11 & 238.00 & 2618.00 & 84.04 \\
\hline & V07AB & $0.9 \%$ sodium chloride $500 \mathrm{~mL}$ & 720 & 3.54 & 2548.80 & 85.01 \\
\hline & V07AB & $5 \%$ dextrose $500 \mathrm{~mL}$ & 630 & 3.90 & 2457.00 & 85.94 \\
\hline & A03FA03 & $\begin{array}{l}\text { Domperidone } \\
10 \mathrm{mg} / 20 \mathrm{~mL} \text { dropper vial }\end{array}$ & 165 & 14.25 & 2351.25 & 86.83 \\
\hline & J01XA01 & Vancomycin hydrochloride $1 \mathrm{~g}$ vial & 157 & 14.90 & 2339.30 & 87.72 \\
\hline & V07AB & $10 \%$ dextrose $500 \mathrm{~mL}$ & & & & \\
\hline & S01AA17 & Erythromycin $5 \mathrm{~g}$ & 352 & 6.50 & 2288.00 & 88.59 \\
\hline & & ophthalmic ointment capsules & 421 & 4.80 & 2020.80 & 89.36 \\
\hline & B01AB01 & $\begin{array}{c}\text { Heparin sodium } 5000 \mathrm{IU} \\
\text { vial }\end{array}$ & 100 & 19.90 & 1990.00 & 90.11 \\
\hline & J01CA01 & $\begin{array}{l}\text { Ampicillin sodium } 1 \mathrm{~g} \\
\text { vial }\end{array}$ & 500 & 3.22 & 1610.00 & 90.73 \\
\hline
\end{tabular}

ATC: Anatomical Therapeutic Chemical Classification 
drugs. However, the number of different drugs in that study corresponded to their use in the neonatology units of 6 hospitals, ${ }^{6}$ while the 102 drugs in our study had been distributed to the Division of
Neonatology of just one hospital. Another study mentioned the use of 33 drug substances in a neonatal intensive care unit without specifying how many drugs they correspond to. ${ }^{22}$

TABLE 3. Comparison of information on the use of drugs in the Neonatology Division obtained from different sources

\begin{tabular}{|c|c|c|c|c|c|}
\hline DRUG & ATC CODE & ANMAT & SAP & COMRA & CONAMED \\
\hline $\begin{array}{l}\text { Exogenous } \\
\text { surfactant } 120 \mathrm{mg}\end{array}$ & R07AA & $\begin{array}{l}2 \text { pharmaceutical products. The } \\
\text { use in newborn infants is not } \\
\text { described }\end{array}$ & YES & $\begin{array}{l}\text { Newborn infants or } \\
\text { premature infants }\end{array}$ & $\begin{array}{l}\text { Premature } \\
\text { infants }\end{array}$ \\
\hline $\begin{array}{l}\text { Liposomal } \\
\text { amphotericin } 50 \mathrm{mg}\end{array}$ & J02AA01 & $\begin{array}{l}2 \text { pharmaceutical products. The } \\
\text { use in newborn infants is not } \\
\text { described }\end{array}$ & YES & $\begin{array}{l}\text { Not found in } \\
\text { the formulary }\end{array}$ & $\begin{array}{l}\text { Not found in } \\
\text { the formulary }\end{array}$ \\
\hline Meropenem $500 \mathrm{mg}$ & J01DH02 & $\begin{array}{l}9 \text { pharmaceutical products. } \\
\text { Only } 1 \text { describes the dose } \\
\text { for children under } \\
3 \text { months old }\end{array}$ & YES & $\begin{array}{l}\text { It describes its } \\
\text { use as of } \\
3 \text { months old }\end{array}$ & $\begin{array}{l}\text { Use is accepted } \\
\text { in children over } \\
3 \text { months old }\end{array}$ \\
\hline Insulin & A10AB01 & $\begin{array}{l}\text { The use in newborn infants } \\
\text { is not mentioned }\end{array}$ & YES & $\begin{array}{l}\text { The use in newborn } \\
\text { infants is not mentioned }\end{array}$ & $\begin{array}{c}\text { The use in newborn } \\
\text { infants is not mentioned }\end{array}$ \\
\hline Albumin $20 \%$ & B05AA01 & $\begin{array}{l}4 \text { pharmaceutical products. } \\
\text { The use in newborn infants } \\
\text { is not mentioned }\end{array}$ & YES & $\begin{array}{l}\text { The use in } \\
\text { newborn infants is } \\
\text { not mentioned }\end{array}$ & $\begin{array}{c}\text { The use in } \\
\text { newborn infants is } \\
\text { not mentioned }\end{array}$ \\
\hline Folic acid drops & В03ВВ01 & $\begin{array}{l}2 \text { pharmaceutical products. } \\
\text { The use in newborn infants } \\
\text { is not mentioned }\end{array}$ & YES & $\begin{array}{l}\text { The use in } \\
\text { newborn infants is } \\
\text { not mentioned }\end{array}$ & $\begin{array}{l}\text { It is described in children. } \\
\text { The use in newborn } \\
\text { infants is not mentioned }\end{array}$ \\
\hline $\begin{array}{l}\text { Erythropoietin } 2000 \\
\text { IUI }\end{array}$ & B03XA01 & $\begin{array}{l}3 \text { pharmaceutical products. } \\
\text { Only } 1 \text { mentions its use in } \\
\text { premature infants }\end{array}$ & YES & $\begin{array}{l}\text { Low birth weight } \\
\text { premature infants }\end{array}$ & $\begin{array}{l}\text { The use in } \\
\text { newborn infants is } \\
\text { not mentioned }\end{array}$ \\
\hline Amino acids $10 \%$ & B05XB & $\begin{array}{l}4 \text { pharmaceutical products. } \\
\text { The use in newborn infants } \\
\text { is not described }\end{array}$ & $\mathrm{NO}$ & $\begin{array}{l}\text { Neonatos y } \\
\text { Newborn infants and } \\
\text { small children }\end{array}$ & $\begin{array}{l}\text { Children weighing } \\
\qquad<10 \mathrm{~kg}\end{array}$ \\
\hline Alprostadil $500 \mu \mathrm{g}$ & C01EA01 & $\begin{array}{l}3 \text { pharmaceutical products. } \\
\text { Only } 1 \text { mentions its use in } \\
\text { premature infants }\end{array}$ & YES & Not described & $\begin{array}{l}\text { Newborn infants with } \\
\text { congenital heart defects }\end{array}$ \\
\hline $\begin{array}{l}\text { Domperidone } \\
\text { drops }\end{array}$ & A03FA03 & $\begin{array}{l}2 \text { pharmaceutical products. } \\
\text { The use in newborn infants } \\
\text { is not mentioned }\end{array}$ & YES & $\begin{array}{l}\text { It is described in children. } \\
\text { The use in newborn } \\
\text { infants is not mentioned }\end{array}$ & $\begin{array}{l}\text { It is described in children. } \\
\text { The use in newborn } \\
\text { infants is not mentioned }\end{array}$ \\
\hline Vancomycin $1 \mathrm{~g}$ & J01XA01 & $\begin{array}{l}9 \text { pharmaceutical products. } \\
\text { The use in newborn infants is } \\
\text { mentioned in all of them }\end{array}$ & YES & $\begin{array}{l}\text { It is described in children. } \\
\text { The use in newborn } \\
\text { infants is not mentioned }\end{array}$ & $\begin{array}{l}\text { Newborn infants up to } \\
4 \text { weeks old. It describes } \\
\text { doses according to weight }\end{array}$ \\
\hline Erythromycin gel & S01AA17 & $\begin{array}{l}2 \text { pharmaceutical products. } \\
\text { Only } 1 \text { mentions its use in } \\
\text { premature infants }\end{array}$ & $\mathrm{NO}$ & $\begin{array}{l}\text { Prevention of neonatal } \\
\text { conjunctivitis }\end{array}$ & $\begin{array}{c}\text { Neonatal ophthalmitis. } \\
\text { Prevention of neonatal } \\
\text { conjunctivitis }\end{array}$ \\
\hline $\begin{array}{l}\text { Heparin sodium } \\
5000 \mathrm{IU}\end{array}$ & B01AB01 & $\begin{array}{c}4 \text { pharmaceutical products. } \\
\text { The use in newborn infants } \\
\text { is not mentioned }\end{array}$ & YES & $\begin{array}{l}\text { It is described in children. } \\
\text { The use in newborn } \\
\text { infants is not mentioned }\end{array}$ & $\begin{array}{c}\text { The use in newborn } \\
\text { infants is not mentioned }\end{array}$ \\
\hline Ampicillin $1 \mathrm{~g}$ & J01CA01 & $\begin{array}{c}7 \text { pharmaceutical products. } \\
\text { The use in newborn infants } \\
\text { is not mentioned }\end{array}$ & YES & $\begin{array}{l}\text { Children under } 7 \text { days } \\
\text { old }\end{array}$ & $\begin{array}{l}\text { Newborn infants up to } \\
4 \text { weeks old. It describes } \\
\text { doses according to weight }\end{array}$ \\
\hline
\end{tabular}

ATC code: Anatomical Therapeutic Chemical Classification.

ANMAT: medicinal product labels approved by the Drug, Food and Technology Administration of Argentina. ${ }^{9}$

SAP: Neonatal Pharmacopeia of the Argentine Society of Pediatrics. ${ }^{10}$

COMRA: Formulary of the Argentine Medical Confederation. ${ }^{11}$

CONAMED: Formulary of the National Medication Commission. ${ }^{12}$

Shaded code:

White: describes information on the use in neonatology.

Light gray: describes information in the labels of some marketed products.

Dark gray: does not describe information on the use in neonatology. 
Many published neonatology studies review the indications for which such drugs were used or the dosage adaptations necessary for these patients. ${ }^{6,22,23}$ This study recorded all dispensed drugs, but did not evaluate whether they were used nor how they were administered.

Authors think that the number of different drugs could be due to the lack of consensus among professionals at the time of writing protocols or guidelines on the treatment provided in the Division of Neonatology. It can also be noticed that there was no therapeutic formulary in the hospital. Having such formulary would be useful to streamline drug management, supply and use. ${ }^{24}$ This was also observed in relation to drug classification as per their ATC code. One fourth of drugs used were antiinfective and their indications for use, dosage administered or number of patients exposed have not been assessed yet.

The two most widely used anatomical therapeutic groups ( $\mathrm{J}$ and $\mathrm{B}$ ) are consistent with those reported by Neubert, et al. in a study conducted at a neonatal intensive care unit in a teaching hospital, ${ }^{25}$ while the study done by López Martínez showed that the most dispensed therapeutic group was that of antibacterials for systemic use (J01), followed by asthma drugs (R03), where the use of intravenous theophylline is underscored, for the prophylaxis and treatment of neonatal apnea. ${ }^{26}$

In relation to the Pareto's chart, $21(20.58 \%)$ drugs in groups A and B account for $90.73 \%$ of the annual drug expenditure and this, in turn, accounts for $2.38 \%$ of the annual budget assigned to the Department of Pharmacy. ${ }^{23}$

In 2011, liposomal amphotericin B ranked second in the Pareto's chart. The annual expenditure in this drug accounted for $24.86 \%$ and it was used in only one newborn infant. This expense was justified by the scarce stability of amphotericin, ${ }^{27}$ which should be discarded 24 hours following reconstitution. In addition, the Department of Pharmacy does not have an intravenous mix section, intended for the preparation and fractioning of parenteral drugs.

Another relevant characteristic related to drugs in every pharmaceutical market are their authorized indications and conditions of use, which may serve as a reference pattern in a qualitative study on the use of drugs. ${ }^{9}$ In this study, it was reviewed whether referred sources actually mentioned the use of the drug for newborn infants. Information quality and quantity were not assessed. Since there are no drug technical sheets in Argentina, the labels authorized by ANMAT were reviewed, regarding this information as official. Only vancomycin has information about its use in neonatology in the 9 labels of its marketed presentations. In the case of meropenem, erythropoietin, alprostadil and erythromycin, at least one form of each of these drugs contains information for the study group. Based on this, drugs that do not contain information on their use in neonatology in their labels could be considered unlicensed or off-label prescriptions. ${ }^{2}$

Based on other consulted sources of information, which are free and available online, the Neonatal Pharmacopeia of the Sociedad Argentina de Pediatría is the one which has included in its listing $85.7 \%$ of the drugs most used at the NHRC's Division of Neonatology. This was expected to happen because this source of information is specifically intended for this age group. However, this pharmacopeia was updated in 2000 for the last time, and might not contain information on more recently marketed drugs that are currently being used in neonatology.

The rest of the consulted formularies contain more information than labels of marketed products. Such information may also be considered objective because it has been evaluated entire population, data specific to neonatology are not enough.

Besides, given that the Division of Neonatology does not have an institutional formulary accepted by consensus, drug use guidelines or protocols, or access to specific sources of information, whether electronic or manual databases, it is very difficult for pharmacists to be able to focus on clinical activities that may result beneficial for patients.

Based on the drug use pattern of the Division of Neonatology, it will be necessary to look into the conditions of use established by the NHRC for the drugs included in groups A and B, since they require to be carefully indicated because of their characteristics and costs. It is expected to develop future intervention strategies to achieve a more optimal, safe, effective and efficient use of drugs.

This is the first analysis conducted at the NHRC's Department of Pharmacy, an also the first one in the region, aimed at identifying drugs that require a special control because of their high cost, whether to individuals or the community. This is the first step towards improving the quality of professional care provided to this group of patients. 


\section{CONCLUSION}

In 2011, 102 drugs were dispensed to the Division of Neonatology. The most commonly used drugs were antiinfectives for systemic use. After interpreting the Pareto's analysis, it is concluded that 21 drugs accounted for $90.73 \%$ of the annual expenditure. Out of 14, only 1 had information regarding its use in neonatology in all its labels, and 9 were used off-label. The Neonatal Pharmacopeia of the Sociedad Argentina de Pediatría provided information about 12 of the 14 drugs. The two formularies analyzed included information for 9 drugs in neonatology, but these were not necessarily the same ones.

\section{Acknowledgments}

To master Sonia Uema, for reviewing the manuscript.

To Neonatology Division Chief, Rosana Campo, M.D.

To the Nursing Supervisor of the Neonatology Division, Antonia Parrilla, N.R.

To Ivana Giachino, M.D., and Andrea Stratta, M.D.

\section{REFERENCES}

1. Committee on Drugs. Guidelines for ethical conduct of studies evaluate drugs in pediatric populations. Pediatrics 1995;95:286-94.

2. Giglio N, MalozowskiS. Prescripciones fuera de prospecto. Arch Argent Pediatr 2004; 102(2):121-4.

3. Giglio N, Rodríguez Gesto E, Arnaldez F, GrichenerJ. Empleo de medicamentos en un hospital pediátrico: Usos validados y no válidos. En: Libro de resúmenes: $33^{\circ}$ Congreso Argentino de Pediatría. Mar del Plata: 2003. p.166 SP 448. Available at: http://www3.sap.org.ar/congresos/staticfiles/conarpe/libro_resumenes.pdf

4. Giglio N. Farmacología en pediatría y usos de medicamentos no autorizados. Arch Argent Pediatr 2012;110(1):4-7.

5. Ganen Rodríguez O, Herrera Collazo M, Monagas Fernández SA, Alarcón Méndez L. Evaluación Económica de los Medicamentos en elServiciode Neonatología deun Hospital materno de Cuba. Acta Farm. Bonaerense 2006;25(2):274-82.

6. Feal Cortizas B, Barroso Pérez C, Carcelen Andrés J, Fábrega Bosacoma $C$, et al. Utilización de medicamentos en unidades de neonatología de 6 hospitales españoles. Farm Hosp 2003;27(2):69-71.

7. Ochoa Mazarro D, Laosa Zafra O. Manejo de Medicamentos en Pediatría. Parte II. Farmacología y Toxicología. [Online]. In: Govantes Betes J, Lorenzo Velázquez P, Govantes Esteso C. Manual Normon. $8^{\text {a }}$ Ed. Madrid. Laboratorios Normon S.A. 2006.Pág.:387-94. Available at: http:/ / www. normon.es/media/manual_8/capitulo_29.pdf

8. Peiré García MA. Importancia de la farmacología clínica en pediatría. An Pediatr (Barc) 2010;72(2):99-102.

9. Ferraz Vallano A. Estudio de Utilización de Medicamentos. [Online].Barcelona: Fundació Institut Catalá de Farmacología. Servicio de Farmacología Clínica. HospitalUniversitariVall d' Hebron. Universitat Autónoma de
Barcelona. [Accessed on: 09-28-2012] Available at: http:/ / www.icf.uab.es/eums/docs/revisioneum.doc

10. OPS/OMS. Aguilar Girón N, Alessio R. Guía para el Desarrollo de Servicios Farmacéuticos Hospitalarios: Logística de Suministro de Medicamentos. Serie Medicamentos Esenciales y Tecnología. [Online].1997. (52) [Accessed on: 09-17-2012]. Available at: http:/ / www.evirtual.uaslp.mx/ FCQ/farmaciahospitalaria/Documents/logística_SSM. pdf

11. Alfa BETA.net. [Online]. Ciudad Autónoma de Buenos Aires: Alfabeta SACIFyS [updated as of: 05-20-2012; accessed on: 02-22-2012].Available at: http:/ / www.alfabeta. net/mf/

12. WHO Collaborating Centre for Drug Statistics Methodology. [Online]. Oslo Noruega: Centro Colaborador de la OMS para la metodología Estadística de Medicamentos Instituto Noruego de Salud Pública; 1982; [updated as of: 04-19-2011; accessed on: 02-09-2012]. Available at: http:/ / www.whocc.no/atc_ddd_index

13. Iñesta García A. Sobre medicamentos y Farmacoeconomía [Online]. Madrid: Escuela Nacional de Sanidad -Instituto de Salud Carlos III. Ministerio de Ciencia e Innovación; 2011 [Accessed on: 09-17-2012]. Available at: http:/ / www. isciii.es/ISCIII/es/contenidos/fd-publicaciones-isciii/fddocumentos/2011-0966_Sobre_medicamentos_y_farmacoeconomia.pdf

14. FUNDIBEQ Fundación Iberoamericana para la Gestión de la Calidad. [Online]. Madrid: FUNDIBEQ; 1999 [updated as of: 2005; accessed on: 12-22-2011]. Available at: http://www.fundibeq.org/opencms/export/sites/default/PWF/downloads/gallery/methodology/tools / diagrama_de_pareto.pdf

15. American Society of Health-System Pharmacists. ASHP guidelines on medication cost management strategies for hospitals and health systems. Am J Health-Syst Pharm 2008;65:1368-84.

16. Administración Nacional de Medicamentos y Tecnología Médica (ANMAT). [Online]. Ciudad Autónoma de Buenos Aires: Ministerio de Salud Presidencia de la Nación; Agosto 1992; [Accessed on: 02-02- 2012]. Available at: http:// www.anmat.gov.ar/aplicaciones_net/applications/consultas/vademecum/vademecum.asp

17. Sociedad Argentina de Pediatría. Por un niño sano en un mundo mejor. [Online]. Ciudad Autónoma de Buenos Aires: Sociedad Argentina de Pediatría; [accessed on: 03-022012]. Available at: http://www.sap.org.ar/staticfiles/ cd_neo/pro.htm

18. Coronel J, Buschiazzo HO, Cañas M, Mordujovich P, et al. Formulario Terapéutico Nacional COMRA. [Online]. 11 $1^{\text {ra }}$ ed. Capital Federal Argentina. Editorial COMRA; [Accessed on: 03-22-2012]. Available at: http:/ / www.comra. org.ar/formulario_terapeutico.pdf

19. Comisión de Medicamentos de la Fundación CONAMED. Formulario Terapéutico Conamed. [Online]. $4^{\text {ta }}$ Ed. Ciudad Autónoma de Buenos Aires. 2008; Editorial CONAMED; [Accessed on: 03-22-2012]. Available at: http:/ / conamed. org/ftc.pdf

20. Arnau JM, Vallano A. Estudio de utilización de medicamentos. Medicamentos y salud [Online]. 2007 [Accessed on: 07-25-2012]; 3;(2):72-7. Available at: www.femeba.org. $\mathrm{ar} /$ fundacion/quienessomos/Novedades/medicamentosysalud/mysv3n27277.pdf Available at: http:/ / www. femeba.org.ar/fundacion/quienessomos/Novedades/ medicamentosysalud/mysv3n27277.pdf

21. Gobierno de la Provincia de Córdoba. Programática por Objeto de Gasto. Jurisdicción/Entidad: 1.45 Ministerio de Salud. Programa: 458.HOSPITALES DEL INTERIOR 
Subprograma: 24. [Online].Presupuesto Año 2011.Available at:http://www.cba.gov.ar/imagenes/fotos/montos_por_programas2011.pdf

22. Warrier I, Du W, Natarajan G, Salari V, et al. Patterns of drug utilization in a neonatal intensive care unit. J Clin Pharmacol 2006;46(4):449-55.

23. Mata Zubillaga D, López de Armentia SL, Rodríguez Lage C, Alvaro Iglesias E. Adecuación de las prescripciones farmacéuticas en una unidad de cuidados intensivos neonatales. An Pediatr (Barc) 2009;71(3):201-8.

24. Larguía M. Prioridades para el gobierno de la Ciudad de Buenos Aires en la Asistencia Neonatológica. Revista del Hospital Materno Infantil Ramón Sardá[Online]. 2001 [Ac- cessed on:12-12-2012];20(3).p.127-132.Availableat: http:// redalyc.uaemex.mx/pdf/912/91220307.pdf

25. Neubert A, Lukas K, Leis T, Dormann H, Brune K, Rascher W. Drug utilization on a preterm and neonatal intensive care unit in Germany: a prospective, cohort-based analysis. Eur J Clin Pharmacol 2010;66(1):87-95.

26. López Martínez R, Cabañas Poy MJ, Oliveras Arenas M, Clemente Bautista S. Utilización de medicamentos en una UCIneonatal: estudio prospectivo. Farm Hosp 2005;29:26-29.

27. Antibióticos. In: Young T, Mangum B. Neofax. Manual de Drogas Neonatológicas. Buenos Aires: Editorial Médica Panamericana; 2005.Pág.13-14. 